\title{
IMPROVEMENT OF CENTER PIVOT IRRIGATION SYSTEM MANAGEMENT USING WATER-SAVING TILLAGE
}

\author{
Harby Mostafa ${ }^{1} \&$ Yano Antar ${ }^{2}$
}

ABSTRACT

The study aimed to improve the management of center pivot irrigation system. This was achieved by evaluating the use of deficit irrigation (100\%, 85\% and $70 \%$ Etc.) with water saving tillage systems (mulch and strip tillage compared to full tillage) under center pivot irrigation system for corn silage production. Soil moisture content, starch content and agronomic parameters e.g. plant height, leaves area and stem diameter were measured. The experiment was in a "split plots design" with three replicates. The results indicated that aggregate soil water contents in the top $\leqslant 0 \mathrm{~cm}$ of the soil profile followed the same patterns and relative positions for each tillage treatment. Moisture contents of soil in the strip and the mulch practices were mostly statistically similar. Full tillage system and the reduced irrigation regime $(70 \%$ ETc) were significant $(P$ $<0.05)$ inferior for agronomic attributes of corn plants in contrast with its corresponding treatments, and that, the $100 \%$ and $85 \%$ water regimes were statistically similar for almost all parameters. Mean corn silage yields were $9.4 \%$ and $6 \%$ greater for the strip tillage practice than for the full practice with $70 \%$ and $85 \%$ ETc, respectively, but for mulch tillage the yield $4.7 \%$ greater than full tiled with $100 \%$ ETc. The results indicated that deficit irrigation has a positive effect when applying with strip tillage followed by mulch tillage where 15 to $30 \%$ of water can be saved.

Keywords: Deficit irrigation, tillage system, corn silage yield

\section{INTRODUCTION}

The impacts of environmental change, the promotion of bioenergy, rising agricultural prices and the associated increase in 1 agricultural intensity make water increasingly an important factor in the production process.

\footnotetext{
${ }^{1}$ Agric. and Biosys. Eng. Dept., Faculty of Agriculture, Benha University, Egypt; harby.mostafa@fagr.bu.edu.eg

${ }^{1}$ Federal Research Institute for Agricultural Technology, Braunschweig, Germany.
} 
Enhancing crop water productivity through inventive irrigation, tillage and plant residue management techniques that have been axial to agricultural sustainability in many parts of the world may be progressively basic if decision makers are to avoid uneconomic reductions in production due to shortage of water availability.

Precision irrigation technology that can be coupled with water use efficient plough and plant residue management systems and regulated deficit irrigation approaches may be preserving the competitive agricultural capacity of forage systems (Lamm and Aiken, 2007; Mitchell, 2014).

The potential to conserve water at the farm scale depends on the strength of the irrigation system and the obligation of the worker to implement water-saving practices and technologies (Mostafa and Thormann, 2015).

The development of movable sprinkler systems has supplied more than suitable irrigation methods. For all irrigation systems, these tools offer the highest potential for orderly applications as well as being easily adaptable for adaptive control of spatially varied applications. Significant progress has been made in hardware development for the control of center pivots to deliver a precision irrigation system (Evans et al., 2013, Mc-Carthy $\boldsymbol{e t}$ al., 2010).

Tillage is considered as one of the most important farming practices in the plant production because it ease seed germination, controls soil erosion, and improves water infiltration and aeration of soil for good production conditions (Mohamad, 2013).

Minimum-tillage systems, with the purpose of retaining the moisture content of soil, decreasing time needed and reducing fuel consumption, have recently been replacing traditional tillage practices. Furthermore, retaining crop residue on the soil surface can provide a resource of crop nutrients, mend organic matter, increase soil moisture content and infiltration rate (Chaorakam et al., 2009).

Yang et al. (2016) concluded that minimum-tillage with residue mulch resulted in higher yields as compared with deep tillage with residue removal probably because of higher topsoil water content. Minimum- 
tillage with residue mulch with low irrigation maintained high grain yields in spite of eliminating one round of irrigation; therefore, it was more beneficial for wheat crop production.

Iqbal et al. (2007) reported that minimum/reduced tillage coupled with irrigation at or more than 50\% soil moisture depletion level an appropriate practice for the study area.

Conservation tillage is well known as a favorable tillage system that focuses on reducing soil erosion and boost water conservation in soil (Mannering and Fenster, 1983; Yang et al. 2016).

In various national and international practice attempts have been made to reduce the loss of water by means of non-turning soil processing methods against plowing methods, e.g. (Bischoff, 2005; Cantero-Martinez et al., 2007). However, there is still no clear-cut insight into the improvement of water storage capacity and the resulting potential reduction in irrigation.

The aim of this work is to optimize the management of center pivot irrigation system by evaluating the use of deficit irrigation with water saving tillage systems under center pivot irrigation system for corn silage production in order to ultimately save water during irrigation also to adjust the expected higher water demand in the event of a future climate change.

Within the framework of a series of experiments, approaches using adapted soil processing, irrigation technology and irrigation control were investigating to further optimize the yield and water use.

\section{MATERIALS AND METHODS}

The experimental study was done in two succesive seasons (2014 and 2016) at Thuenen Institute for Agricultural Technology (TI), Braunschweig, Germany. It is located between latitudes of $52^{\circ} 1752,80^{\prime} \mathrm{N}$ - 52 1803 'N, and longitudes of $10^{\circ} 271^{\prime \prime E}-10^{\circ} 27370,27$ 'E, respectively. The characteristics of the soil at the experimental site are $1.4 \%$ organic matter, $6.3 \%$ clay, $48.7 \%$ silt, $45 \%$ sand and $6.3 \mathrm{pH}$. The soil type was characterized by a loamy sand texture. The weather data in this region are shown in Table 1. 
Table 1: The average weather data at the experimental site (the German Weather Station "DWD”, www.dwd.de)

\begin{tabular}{l|c|c|c|c|c}
\hline \hline \multirow{2}{*}{ Parameters } & \multicolumn{5}{c}{ Average from 1965 to 2015 } \\
\cline { 2 - 6 } & May & June & July & August & Sep. \\
\hline \hline Precipitation $[\mathrm{mm}]$ & 51 & 70 & 47 & 58 & 50 \\
\hline Temperature $\left[{ }^{\circ} \mathrm{C}\right]$ & 13.1 & 15.9 & 20.4 & 19 & 16 \\
\hline Potential ET $\left[\mathrm{mm} \cdot \mathrm{month}^{-1}\right]$ & 88 & 91 & 94 & 99 & 97 \\
\hline \hline
\end{tabular}

\section{Experimental Setup}

The technical implementation on the trial field was carried out with an existing center pivot system machine with $90 \mathrm{~m}$ length. For water distribution, the center pivot was equipped with rotating plate nozzles (Nelson R3000) mounted at a spacing of $5 \mathrm{~m}$. To keep the flow rate of the nozzle constant over the entire width of the machine, pressure reducing valves (Nelson High Flow 1.38 bar) were placed in front of each nozzle.

The trial was arranged in a split plot design with three irrigation levels in the main plots and three tillage treatments in subplots with three replications. The area was previously cultivated with wheat.

The area of center pivot was divided into four quarters, three of them were used as the main plots (one quarter for each irrigation treatment) under the second tower. The three different soil processing each have a width of $18 \mathrm{~m}$ and extend over a length of $50 \mathrm{~m}$ as subplot. Each subplot was divided to three replicats $(6 \times 50 \mathrm{~m})$ with $6 \mathrm{~m}$ separation line between subplots as shown in fig (1).

The treatments were as follows:

Tillage: (i) Full tillage (FT) with $30 \mathrm{~cm}$ depth,

(ii) Mulch tillage (MT) with 10 to $12 \mathrm{~cm}$ depth, and

(iii) Strip tillage (ST) with $20 \mathrm{~cm}$ wide and 10 to $12 \mathrm{~cm}$ depth.

Irrigation: (i) irrigation at $100 \%$ of water requirements,

(ii) irrigation at $85 \%$ of water requirements, and

(iii) irrigation at $70 \%$ of water requirements. 


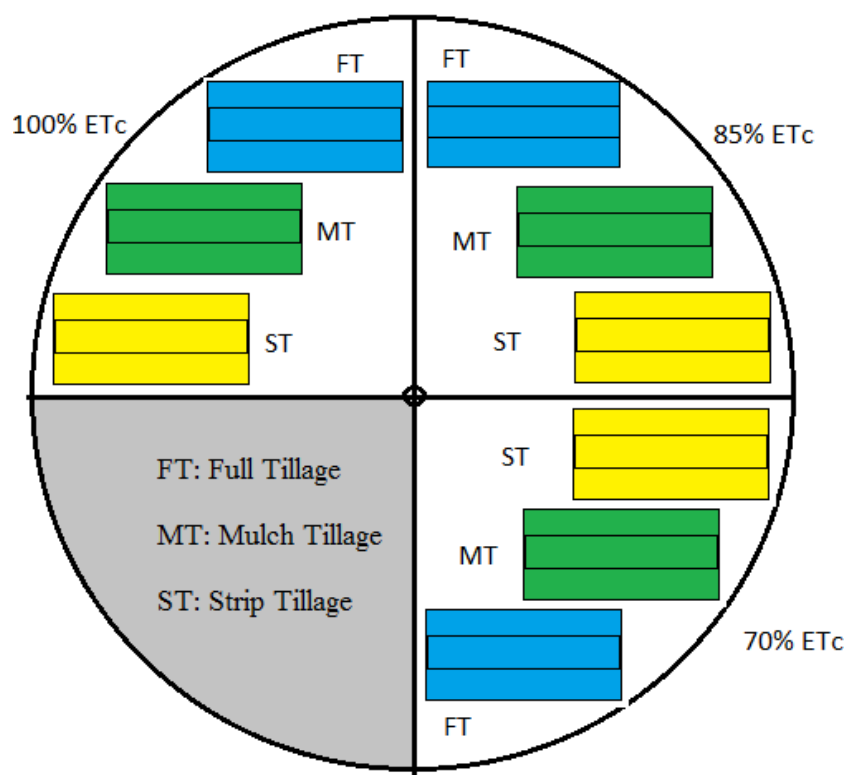

Fig.1: Schematic experimental field systems

The irrigation amount was adapted by controlling the center pivot speed for each quarter to irrigate the require depth.

The full tillage plots were tilled to approximately $30 \mathrm{~cm}$ depth by a rotary cultivator machine attached with underground plow to ensure full incorporation of the preceding crop residue. Mulch tillage (shallow) treatment was tilled to 10 to $12 \mathrm{~cm}$ depth using a three-row heavy cultivator with a double-row short disc harrow follower for mixing and cutting plant residues and a large-sized rod roll for height guidance and re-consolidation. Strip tillage treatment was designed to minimize soil disturbance using a tilling depth of only 10 to $12 \mathrm{~cm}$ and a width of $20 \mathrm{~cm}$ for seed by using a small rotary tiller (Fig 2).

Sufficient irrigation was applied to keep the soil water profile of root zone between critical moisture content and field capacity. Factors for starting and controlling the irrigation system serve the available water capacity (AWC) of the soil which is controlled by the irrigation controller model AMBER that managed by the German Meteorological Service (DWD). The five-day prediction of water demand was created daily and allowed the further specific irrigation. The irrigation starts on all treatments when $75 \%$ of AWC under $100 \%$ ETc irrigation treatment is consumed. 


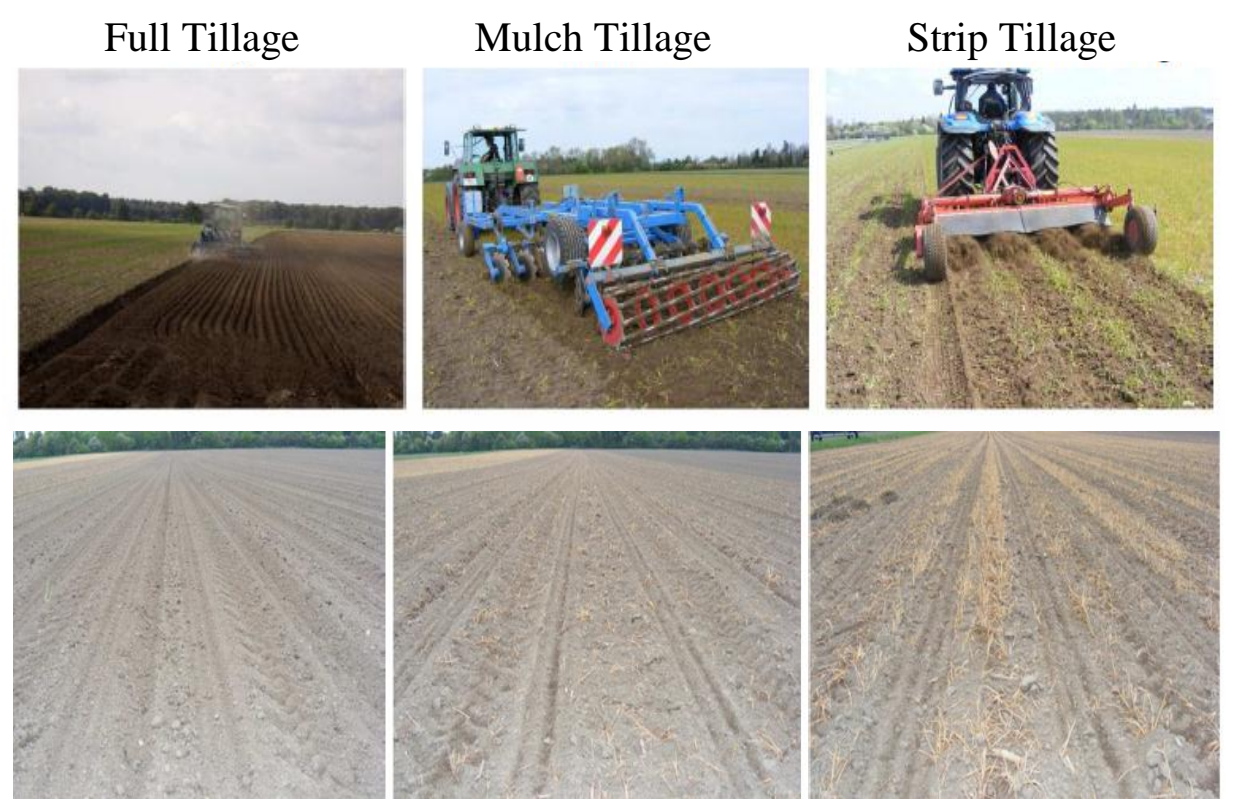

Fig 2: Soil tillage treatments (Full tillage, mulch tillage and strip tillage).

All plots were planted with corn (for silage production) in the second week of May for both two seasons. Corn seeds were planted at a spacing of $0.13 \mathrm{~m}$ within row and $0.75 \mathrm{~m}$ between rows. The soil was tested for needed fertilizer requirements and was added accordingly.

The harvest was done when whole plants moisture was between 65 and $70 \%$ moisture (at the end of September to beginning of October) according to Mostafa and Derbala (2013).

\section{Measurements}

For each plot, the daily moisture content of soil (M.C) was measured using a hand-held $0.40 \mathrm{~m}$ soil moisture probe (Hydrosense probe). By using the data of weather station located next to the experimental site, AMBER modell was used to monitor the daily changes of precipitation rate, temperature, evapotranspiration and create the irrigation requirements. Agronomic parameters e.g. plant height, leaves area and stem diameter were measured directly before harvesting.

To start the harvesting, whole plant moisture at harvest has to be between 65 and $70 \%$. The way to accurately evaluate whole-plant moisture was to 
collect plant samples and have them tested. The materials were put in the drier at a constant weight. Equation 1 was used to calculate the plant MC (\%) (ASHRAE , 1997):

$$
M C(\%)=\frac{\left(W_{m}-W_{d}\right)}{W_{d}} \times 100
$$

Where:

$M C=$ Moisture content in \% $\mathrm{db}$.,

$W_{m}=$ Moist weight in $\mathrm{kg}$ and

$W_{d}=$ Dry weight in $\mathrm{kg}$.

The starch content is presented as an essential quality criterion for animal feeding. The method of starch investigation depends on the principle that starch is totally separated to its constituent glucose sugars while still physically located in the sample. This degradation step is carried out using starch degrading enzymes ( $\alpha$-amylase, $\beta$-amylase and several dextrinases etc), collectively known as 'amyloglucosidase', and which are specific for starch only. The starch content is then calculated from the amount of glucose produced (Rasmussen and Henry, 1990).

On determination of yield and starch content of corn silage, all plots were harvested separately by harvesting machine (which cut and chop plants and placed on containers that can be weighed).

All data collected were statistically analyzed as described by Snedcor and Cochran (1982). Means among treatments were compared using Least Significant Difference (LSD) at P 0.05 probability.

\section{RESULTS AND DISCUSSION}

\section{Moisture Content of Soil}

Soil moisture measurements were collected before irrigation events, thus the data represent a lower boundary of moisture content values. Water contents in soil tended to be the similar trend for all tillage treatments under each irrigation regime from the beginning until the end of the growing season of the study periods.

As shown in Figs (3, 4 and 5), soil moisture contents within the crop root zone were affected by the tillage practices. The strip and mulch tillage practices tended to have the highest soil water content and the full tillage 
practice the lowest under all irrigation regimes. Mean moisture contents for the full tillage practice were between 25 and $27 \%$ under full irrigation $(100 \%$ ETc) and for both mulch and strip tillage practices were between 28 and $31 \%$ (Fig 3).

A statistical analysis of the data indicated that there are no-significant differences between all tillage practices under $100 \%$ irrigation regime.

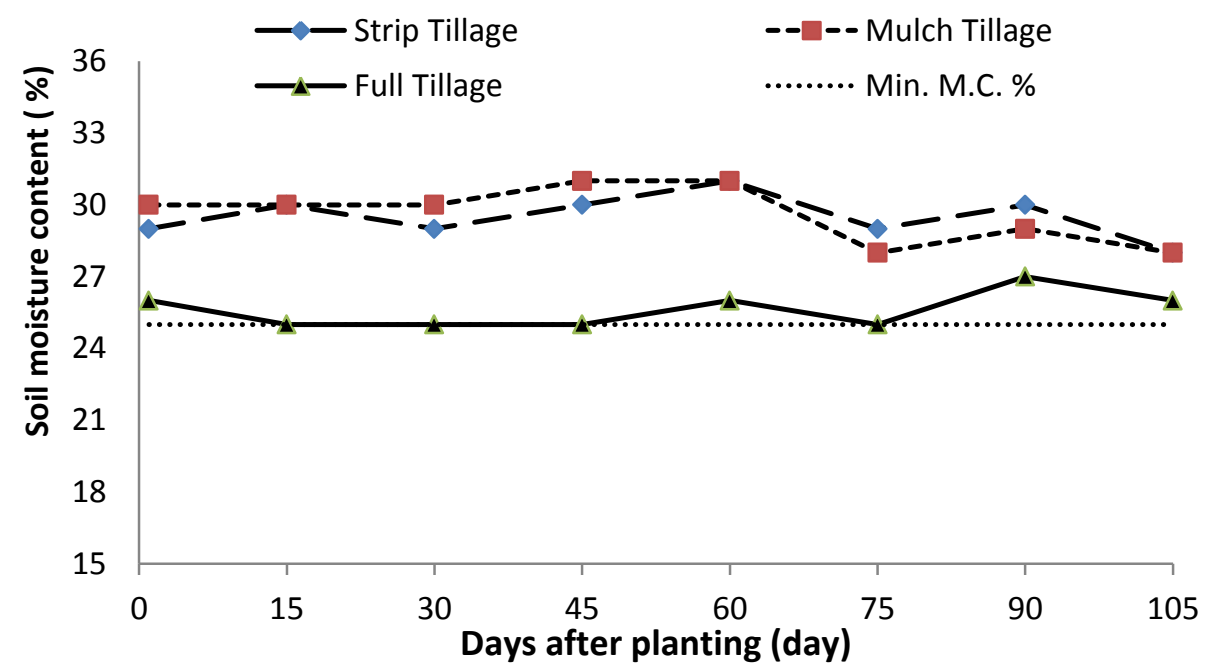

Fig (3): Change in moisture content of soil during growth period at 100\% ETc

With water regimes $85 \%$ and $70 \%$ ETc, the data take the same trend. There were no-statistical differences between the mulch and strip tillage treatments with $85 \%$ ETc, where moisture content of soil were 26 to $28 \%$ and 27 to 29\%, respectively (Fig 4). Also, the moisture content with $70 \%$ Etc ranged between 21 to $25 \%$ for mulch tillage and between 23 to $25 \%$ for strip tillage (Fig 5). On the contrary, soil moisture content showed the lowest values in the full tillage in both $85 \%$ and $70 \%$ ETc irrigation regime. The statistical analysis indicated that soil moisture content was significantly influenced by tillage practices and water regimes. These results agreed with (Mitchell, 2014), after sustained conservation tilled production, soils may store more water than traditionally ploughed soils because of the upkeep of macropores. Moreover, soils with stubble cover additionally decrease wind speeds and temperatures at the surface, which may decrease evaporation from the soil, saving water and enhancing the 
production efficiencies in cropping systems. Likewise Gozubuyuk $\boldsymbol{e t}$ al. (2014) and (2015); Badalikova (2010) and Romaneckas et al. (2013) detailed that reduction of soil tillage intensity from annual deep tiled to shallow tiled, deep, shallow and no tillage save soil moisture content and the micropores could increment because of the reduction in macroporosity under no tillage conditions.

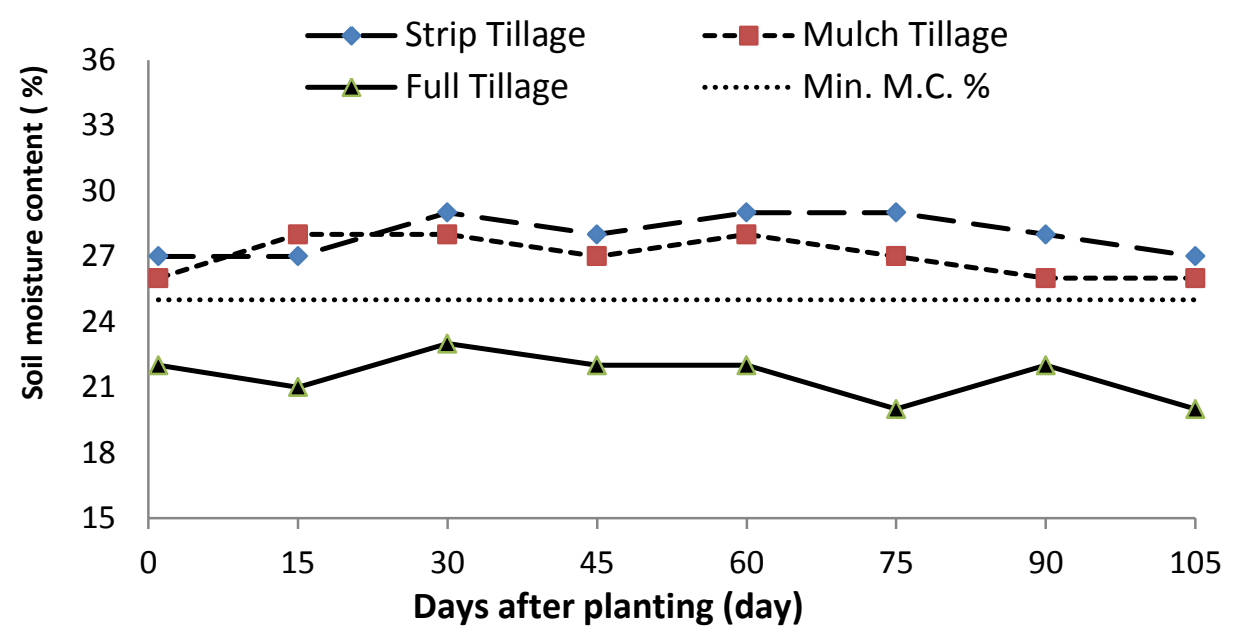

Fig (4): Change in moisture content of soil during growth period at $85 \%$ ETc

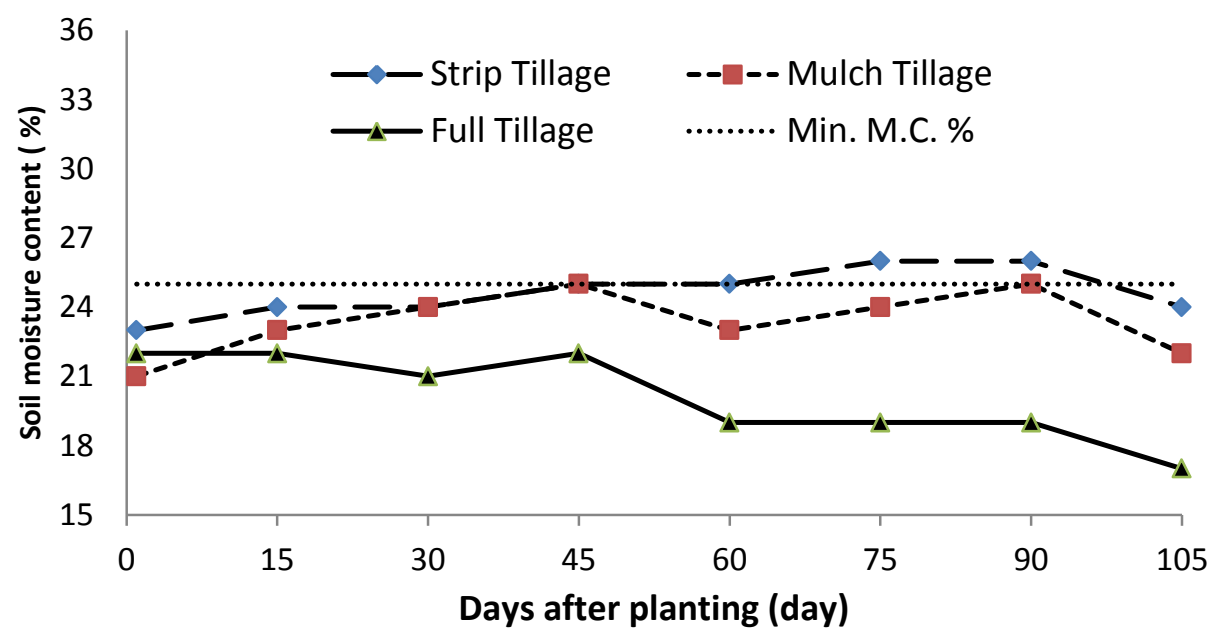

Fig (5): Change in moisture content of soil during growth period at 70\% ETc 


\section{Effect of water regimes and tillage treatments on agronomic growth parameters}

Data in Table (2) contain the effect of water regimes and tillage treatments on agronomic growth parameters (plant height, leaves area and stem diameter). Data in the aforementioned tables indicated clearly that irrigation water regimes affected significantly corn agronomic growth parameters under full and mulch tillage systems. Generally, it could be safely concluded that changing the irrigating corn plants from 70 to $100 \%$ of Etc led to obtaining significant values of the aforementioned agronomic growth parameters in most sampling data. It is noteworthy to mention that the $100 \%$ Etc treatment exhibited similar effect on agronomic growth parameters as the $70 \%$ Etc with strip tillage. Also, tillage systems affected significantly the agronomic growth parameters. Mulch tillage treatment showed a highest value with $100 \%$ Etc for all parameters, while strip tillage treatment showed a highest values with $85 \%$ and $70 \%$ Etc. Results indicated that interaction had significant effects on most studied growth parameters. The highest values of plant height $(225 \mathrm{~cm})$ and stem diameter $(3.22 \mathrm{~cm})$ were observed by applying $100 \%$ Etc under mulch tillage system and with $85 \%$ and $70 \%$ Etc strip tillage showed the highst valoues. On the other hand, the irrigation with $70 \%$ Etc under full tillage system showed the lowest values.

Table (2): Effect of water regime and tillage types on plant length $(\mathrm{cm})$, stem diameter $(\mathbf{m m})$ and leaf area.

\begin{tabular}{|c|c|c|c|c|c|c|c|c|c|}
\hline \multirow[b]{2}{*}{ Till. System } & \multicolumn{3}{|c|}{ Plant length $(\mathrm{cm})$} & \multicolumn{3}{|c|}{ stem diameter $(\mathrm{cm})$} & \multicolumn{3}{|c|}{ Leaf area ${ }^{*}\left(\mathrm{~cm}^{2}\right)$} \\
\hline & $70 \%$ & $85 \%$ & $100 \%$ & $70 \%$ & $85 \%$ & $100 \%$ & $70 \%$ & $85 \%$ & $100 \%$ \\
\hline Full Tillage & $198^{a}$ & $210^{a}$ & 220 & $2.52^{\mathrm{a}}$ & 2.96 & 3.15 & $602.1^{a}$ & $675.2^{\mathrm{a}}$ & $742.5^{\mathrm{a}}$ \\
\hline Mulch Tillage & $207^{\mathrm{ab}}$ & $214^{\mathrm{ab}}$ & 225 & $2.71^{\mathrm{a}}$ & 3.12 & 3.22 & $671.3^{b}$ & $692.1^{\mathrm{ab}}$ & $789.7^{b}$ \\
\hline Strip Tillage & $217^{b}$ & $222^{b}$ & 222 & $3.1^{\mathrm{b}}$ & 3.22 & 3.15 & $731^{c}$ & $746.3^{b}$ & $747.8^{a}$ \\
\hline LSD (0.05) & 11 & 10 & 7 & 0.36 & 0.4 & 0.29 & 38.1 & 70.5 & 40.6 \\
\hline
\end{tabular}

${ }^{*}$ Leaf area $=0.75$ (max. width $x$ length of the leaf) (Abou Kheira, 2009) 


\section{Starch Contents}

In the case of the differences in the starch content between the three soil tillage treatments, it can be seen in Fig (6) that the strip tillage plots have achieved the highest yields and the full tillage variants the lowest yields with all irrigation regimes. In the case of the $70 \%$ Etc, the strip tillage has the highest starch content followed by mulch tillage treatments with nonsignificant effects, but the full tillage showed a significant reduction. The same trend was happend in the case of $85 \%$ Etc. There is no-significant effects between $70 \%$ and $85 \%$ Etc for each tillage treatment, but $100 \%$ Etc showed significant deferances between all tillage treatments and also comparable with the other irrigation regimes.

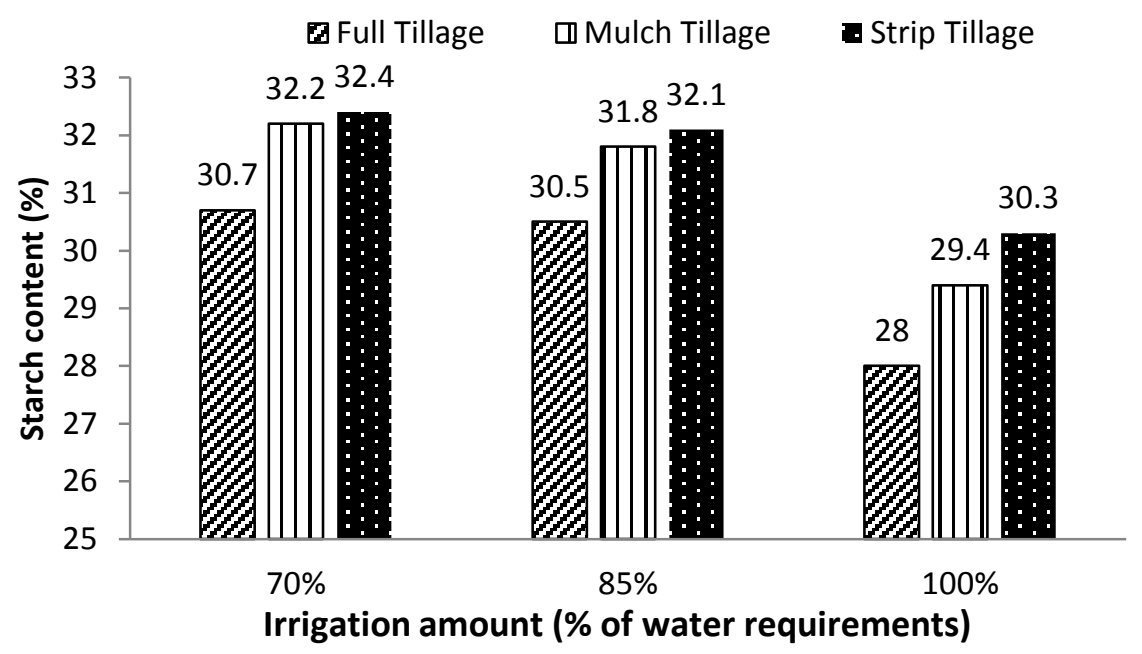

Fig (6): Change in starch content (\%) in corn silage.

\section{Silage Yield and Water use efficiency (WUE, $\mathrm{kg} / \mathrm{m}^{\mathbf{3}}$ )}

The final yield of the silage was affected by both irrigation regimes and tillage types as shown in Fig (7). Mulch tillage gave statistically significant ( $\mathrm{p}$ 0.05) higher silage yield than full and strip tillage under $100 \%$ ETc reaching $24.2 \mathrm{t} \mathrm{ha}^{-1}$ compared to 23.1 and $23 \mathrm{tha}^{-1}$ of the full and strip tillage, respectively. Strip tillage system also resulted to statistically significant higher yield than mulch tillage system (p 0.01) and full tillage system ( $\mathrm{p}$ 0.05) reaching $23.4 \mathrm{tha}^{-1}$ compared to 22.8 and 22.1 $\mathrm{t} \mathrm{ha}^{-1}$ with $85 \%$ ETc, and $22.3 \mathrm{tha}^{-1}$ compared to 21.6 and $20.2 \mathrm{t} \mathrm{ha}^{-1}$ with 
$70 \%$ ETc of the mulch and full tillage, respectively. As it was expected, silage yield was influenced by irrigation regime, where the yield reduction was 2.9 and $2.6 \mathrm{t} \mathrm{ha}^{-1}$ for both full and mulch tillage, respectively but the less reduction was $0.7 \mathrm{t} \mathrm{ha}^{-1}$ for strip tillage when the irrigation was reduced from 100 to $70 \%$ ETc. These results agreed with those obtained by Yang et al. (2016).

It is obvious that WUE $\left(\mathrm{kg} / \mathrm{m}^{3}\right)$ was lower in plots that got $100 \%$ ETc water regime (average of $8.6 \mathrm{~kg} / \mathrm{m}^{3}$ ). On the other hand, the highest values for WUE were accounted for regarding $70 \%$ ETc water regime (averaged $10.8 \mathrm{~kg} / \mathrm{m}^{3}$ ). These results agreed with those obtained by Mostafa and Derbala (2013).

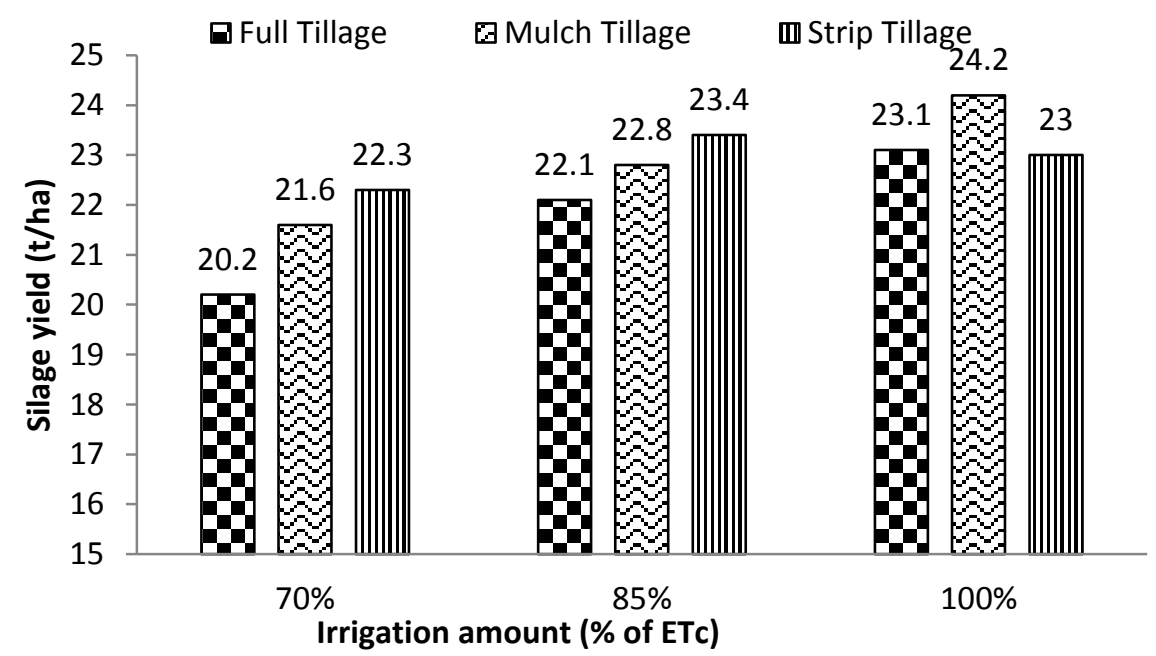

Fig (7): Average yield of corn silage under different tillage methods and irrigation regimes.

\section{CONCLUSION}

All Investigation of the moisture content data demonstrates that water content values for mulch and strip tillage practices tend to be interchangeableness in rank and that the full tillage values were the most reduced to all irrigation regimes. Aggregate moisture contents of soil in the top $40 \mathrm{~cm}$ of the soil profile followed the same patterns and relative 
positions for each treatment. Water contents of soil in the strip and the mulch practices were mostly statistically similar.

Full tillage and the reduced irrigation regime $(70 \%$ ETc) were significant $(\mathrm{P}<0.05)$ inferior for agronomic attributes of corn plants in contrast with its corresponding treatments, and that, the $100 \%$ and $85 \%$ water regimes were statistically similar for almost all parameters. Mean corn silage yields were $9.4 \%$ and $6 \%$ greater for the strip tillage practice than for the full practice with $70 \%$ and $85 \% \mathrm{ETc}$, respectively, but for mulch tillage the yield $4.7 \%$ greater than full tillage with $100 \%$ ETc. The results indicate that deficit irrigation was well effective when applying with strip tillage followed by mulch tillage where 15 to $30 \%$ of water can be saved.

\section{ACKNOWLEDGEMENT}

The authors thank the Braunschweig DWD and Thünen Institute for Agronomy for the good cooperation. The first author would like to present deep gratefulness and appreciation to Thünen Institute for Agricultural Technology (TI), Braunschweig, Germany, for giving him the opportunity to fulfill this study.

\section{REFERENCES}

Abou Kheira, A. A. (2009). Comparison among different irrigation systems for deficit-irrigated corn in the Nile Valley. Agricultural Engineering International: The CIGR Journal Manuscript LW 08 010. vol. XI.

ASHRAE. (1997). ASHRAE Handbook, Fundamentals. American Society of Heating and Refrigerating and Air Conditioning Engineers, Inc., New York.

Badalikova, B. (2010). Influence of soil tillage on soil compaction. In: Dedousis, A.P., Bartzanas, T. (Eds.), Soil Engineering, Soil Biology 20. Springer-Verlag, Berlin Heidelberg, pp. 19-30.

Bischoff, J. (2005). Tillage and water costs. New Agriculture, 2, 38-39.

German Co. of Agriculture publisher, Hanover, Germany. (in German). 
Cantero-Martínez, C., P. Angás and J. Lampurlanés (2007). Long-term yield and water use efficiency under various tillage systems in Mediterranean rainfed conditions. Annals of Applied Biology 150: 293-305.

Chaorakam I., M. Koike, T. Takigawa, A. Yoda, H. Hasegawa and B. Bahalayodhin (2009). Field evaluation of slot openers for minimum tillage (part 3)- Dried soil cover on the slot. Mj. Int. J. Sci. Tech., 1(Special Issue), 95-105

Evans, R. G., J. LaRue, K. C. Stone, and B.A. King (2013). Adoption of site-specific variable rate sprinkler irrigation systems. Pub. from USDA-ARS / UNL Fac. Paper 1245. http://digitalcommons.unl.edu/usdaarsfacpub/1245.

Gozubuyuk Z., U. Sahin, M. C. Adiguzel, I. Ozturk and A. Celik (2015). The influence of different tillage practices on water content of soil and crop yield in vetch-winter wheat rotation compared to fallowwinter wheat rotation in a high altitude and cool climate. Agricultural Water Management 160: 84-97

Gozubuyuk, Z., U. Sahin, I. Ozturk, and M. C. Adiguzel (2014). Tillage effects on certain physical and hydraulic properties of a loamy soil under a crop rotation in a semi-arid region with a cool climate. Catena 118, 195-205.

Iqbal M., M. Ahmad, M Ahmad, M. lqbal and M. Ali (2007). Wheat response to tillage and irrigation. Pak. J. Agri. Sci., Vol.44(1)

Lamm F. R. and R. M. Aiken (2007). Tillage and Irrigation Capacity Effects on Corn Production. ASABE Annual International Meeting, Minnesota, 17 - 20 June.

Mannering, J V. and C.R. Fenster (1983). What is conservation tillage? J. Soil Water Conserv., 38, 140-143.

McCarthy, A.C., N.H. Hancock, and S.R. Raine (2010). VARIwise: A general-purpose adaptive control framework for spatially and 
temporally varied irrigation at sub-field level. Computers and Electronics in Agr., 70: 117-128.

Mitchell, J. (2014). Precision irrigation and conservation tillage: A plan for improving forage production systems. Proceedings, California Alfalfa, Forage, and Grain Symposium, Long Beach, CA, 10-12 December, 2014. UC Cooperative Extension, Plant Sciences Department, University of California.

Mohammed, S.A.A. (2013). Contribution of weed control and tillage systems on soil moisture content, growth and forage quality of (Clitoria \& Siratro) mixture under-rainfed conditions at Zalingei western Darfur state - Sudan. ARPN J. Sci. Technol. 3, 80-95.

Mostafa, H. and A. Derbala (2013). Performance of supplementary irrigation systems for corn silage in the sub-humid areas. Agric. Eng. Int.: CIGR Journal, 15(4): 9-15.

Mostafa H. and H.H Thörmann (2015). Site-specific pivot sprinkler assessed for saving water in agriculture. Misr J. Ag. Eng., 32(2).

Rasmussen T. S. and R. J. Henry (1990). Starch determination in horticultural plant material by an enzymic-colorimetric procedure. J. Sci. Food Agric., 52, 159 - 170

Romaneckas K., E. Šarauskis, L. Masilionytè, A. Sakalauskas and V. Pilipavičius (2013). Impact of different tillage methods on silty loam luvisol water content in sugar Beet (Beta vulgaris L.) Crop. Journal of Environmental Protection, 4, 219-225, http://dx.doi.org/10.4236/jep.2013.43026

Snedcor, G.W. and W.G. Cochran (1982). Statistical methods. 7th Ed, The Iowa State University Press, Iowa.

Yang X., C. Yin, H. Chien, G. Li, and F. Nagumo (2016). An evaluation of minimum tillage in the corn-wheat cropping system in Hebei Province, China: Wheat Productivity and water conservation. JARQ 50 (3) 191-199. 


\section{الملخص العربي}

\section{تحسين إدارة نظام الرى المحورى باستخدام الحراثة الموفرة للمياه}

\section{حربى مصطقى' ، يانو أنتر'}

تم إجراء التجارب الحقليه فى معهد التكنولوجيا الزراعية بالمركز الفيدرالى للبحوث

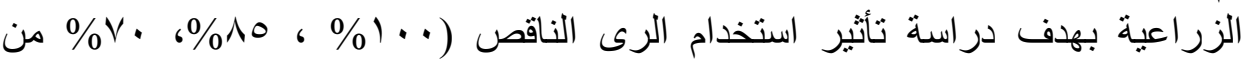
الاحتياجات المائية) مع نظم الحراثة الموفرة للمياه (الحر اثثة العميقة ـ حر اثنة سطحية مع

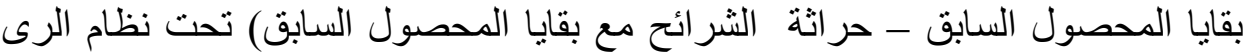

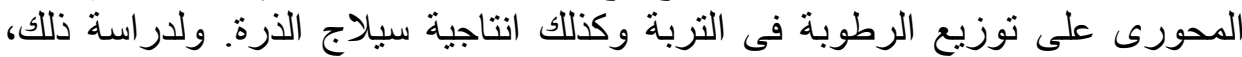
وز عت المعاملات بنظام القطع المنشقة وثلاثثة مقررات. أوضحت النتائج أنه لم يكن هنالك

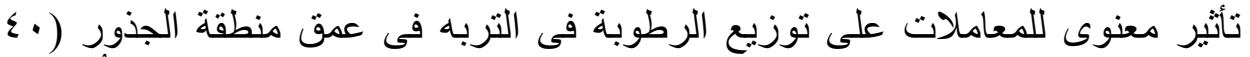

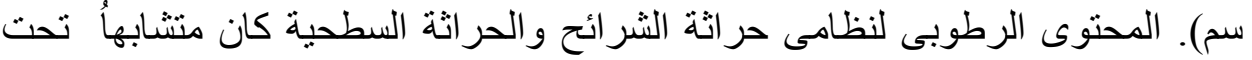

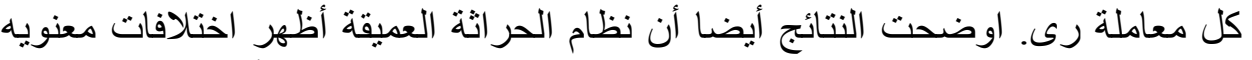

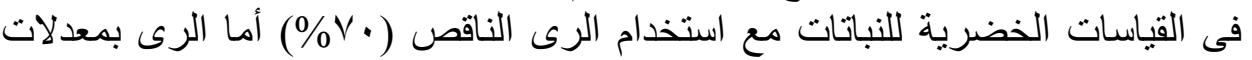

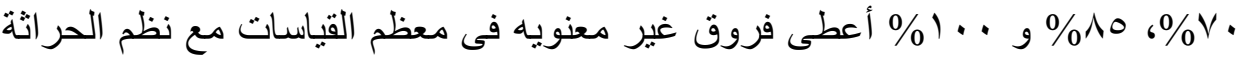

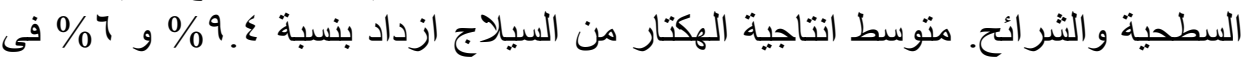

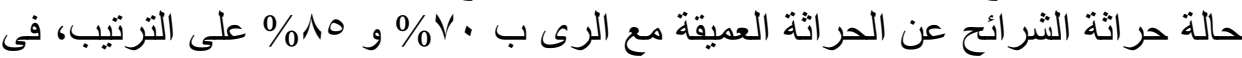

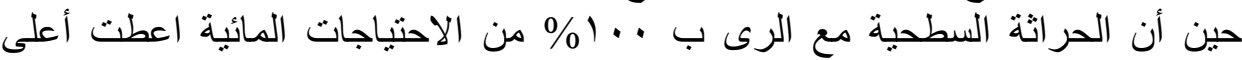

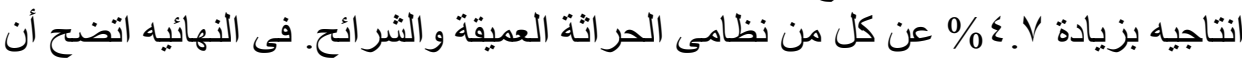
استخدام الرى الناقص لله تأثير إجابى فى الحفاظ على معدل الانتاجيه مع توفير مياه الرىى بنسبة 10\% و ، \% \% تحت نظم الحراثة السطحية و الثرائح مع بعض بقايا المحصول السابق على الترتيب. 